\title{
The Effect of Online Project-Based Learning Application on Mathematics Students' Visual Thinking Continuum in Covid-19 Pandemic
}

\author{
https://doi.org/10.3991/ijim.v15i08.21565 \\ Sapti Wahyuningsih ${ }^{\bowtie}$, Abd. Qohar, Darmawan Satyananda \\ Universitas Negeri Malang, Java, Indonesia \\ sapti.wahyuningsih. fmipa@um.ac.id \\ Noor Azean Atan \\ Universiti Teknologi Malaysia, Johor, Malaysia
}

\begin{abstract}
The COVID-19 pandemic led to the implementation of the Work from Home (WFH) policy. The impact of this policy is to replace the process of teaching and learning activities by using an online learning system. In this industrial era 4.0, the integration of web applications is very much needed in problem-solving learning. One that can be used to integrate web applications in learning through project-based learning. The focus of this research is to study the effects of online project-based learning applications on mathematics students' visual thinking continuum. Instruments used in the form of rubric virtual mind maps, audio-visual and virtual posters are used to observe students' visual thinking continuum. The instrument was analyzed with the Rasch measurement model software named WINSTEPS. This study used one group pretest-posttest design to see the effect of integrating web applications in learning through project-based learning analyzed using SPSS. The results of instrument analysis for rubric virtual mind maps, audio-visual products, and virtual posters on measure person obtained good person reliability, MNSQ infit, and MNSQ OUTFIT the average rating is very good. For the ZSTD infit and the ZSTD outfit, the average value is close to 0.0 so that the quality of the person's reliability is good. The results of the conformity quality of the items with the model studied from the fit order items obtained the value of Outfit mean square (MNSQ), Outfit Zstandard (ZSTD), and the value of Point Measure Correlation (Pt Mean Corr) for the three instruments met good criteria. The results of the analysis of paired samples test from 54 respondents obtained $\mathrm{p}<0.05$ so that the base learning project has the effect of increasing students' visual thinking continuum. Implementation of online project-based learning in mathematics learning is an alternative that can be used to improve students' creative problem-solving skills in online learning.
\end{abstract}

Keywords - Project-based learning, visual thinking, visual learning, visual communication, and Rasch measurement model 


\section{Introduction}

\subsection{Background}

The existence of the COVID-19 pandemic led to the implementation of the Work From Home (WFH) policy. This policy is an attempt by the government with the goal that the public conduct physical distancing, to reduce the spread of COVID-19. Education in Indonesia has also become one of the areas affected by the COVID-19 pandemic. The Ministry of Education in Indonesia issued a policy by dismissing schools and universities and replacing the teaching and learning process by using an online learning system. Not only in Indonesia, but had the impact of this pandemic also felt in other countries. Italy utilizes virtual teaching policies on campus [1], just as the adaptation of education and training in medicine in the Department of Medicine, Perelman School of Medicine at the University of Pennsylvania [2].

The impact of increasingly sophisticated technology disruption and the demand for online learning, forcing students and teachers to master the technology that supports the learning system. This requires the support of the adaptation of learning strategies. Some of them can be seen in New Zealand that use blended learning [3], virtual learning in Harvard Medical School [4], online use of modules to teach nursing students [5], online learning in developed countries [6] examined elementary teachers' use of online learning [7], [8], and online education [9].

Adaptation of learning strategies for mastering concepts online can use mind maps. Some related research discusses mind maps, such as mind mapping in the learning models [10], e-learning in mind maps of the Czech and Kazakhstan universities [11], and the use of virtual mind mapping [12]. The effectiveness of mind maps in education can be seen in [13]-[19]. The mind map is a visual thinking application that has an important role in learning mathematics. Creativity and visual thinking contribute to the learning of mathematics. This can be seen in [20], creative problems with visual thinking in [21], and the implementation of creative and visual media problems in schools [22].

Subsequent research developed from visual thinking to the visual thinking continuum. A discussion of the visual thinking continuum can be seen in [23]. The visual thinking continuum on the implementation of learning includes visual thinking, visual learning, and visual communication. Some studies on visual learning for example [24] - [27]. Visual learning has an important role in learning, applied in the form of audiovisual media. In addition to visual thinking and visual learning, visual communication also has an important role. Some studies on visual communication for example [28][31]. Visual communication applications in this study can be in the form of posters that can facilitate the delivery of problem-solving. This can be seen in several studies [8], [32] - [34].

In the era of the industrial revolution, 4.0 web application integration is needed in the learning process of problem-solving. One learning model that can be integrated with web applications is project-based learning (PBL). This learning model can help students to have creative thinking, sharpen problem-solving skills, practice interacting, and assist in investigations that lead to solving real problems. The focus of learn- 
ing involves students in problem-solving investigations and activities of meaningful tasks that have great potential to provide a more interesting and meaningful learning experience for students.

Some previous studies on project-based learning development can be seen in [35] [42]. PBL has a positive effect on learning and its results, this can be seen in [43] [45]. Researches on linking PBL with ICT are in [46] - [49]. While research on the combination of online learning with project base learning is discussed by [47],[49] [51]. Through the teaching and learning process, student creativity can be nurtured and developed in facing problems solving problems.

The characteristics of the graph theory application course can be applied to real problems. The choice of the PBL model is following the characteristics of this course. Based on the positive impact of the PBL and the characteristics of the course, the PBL model is implemented in learning the application of graph theory. Students determine projects that are solved by conducting field surveys in relevant industries or institutions. E-project products made by students in the form of virtual mind maps, audiovisuals, and virtual posters are discussed in this article. Rasch model is used to analyze the quality of the instruments.

\subsection{Literature review}

Virtual mind maps as the implementation of visual thinking is needed in identifying and understanding the structure of the subject, presenting an overall picture of something in a shorter time, improving recording information speed, supporting and improving creative problem-solving. Each virtual mind maps is very unique that easy to remember and deliver brief information because it only uses keywords. Students design virtual mind maps in working on projects shared online using mobile devices. Previous studies that support this opinion are [10] - [12], [16], [17], [19].

Visual learning is implemented by audio-visual media. Media that displays motion is informative, educative, and instructional, which provide meaningful experiences, aside to develop and expand the horizons of critical thinking. Previous studies that support this opinion are [24]- [27], [52], and [53].

The virtual poster is one form of visual communication. The virtual poster is illustrations of simplified object images so that they can highlight the power of messages and visuals, using colors to express the idea of a particular fact or event. Students design the virtual poster in working on projects shared online using mobile devices. Some studies that support this opinion are [30], [33], [34].

\section{Research Objectives}

To know the effect of online project-based learning on the Application of Graph Theory course, research objectives: 1). Analyze the visual thinking continuum instrument using the Rasch measurement model, 2). To examine the effects of online project-based learning on students' visual thinking continuum. 


\section{$3 \quad$ Research Methodology}

\subsection{Research design}

The goal of the Application of Graph Theory course is for students can make a problem-solving project by applying a concept in graph theory. Data on the problem is a real problem taken from field surveys in the industry. The product of this eproject is in the form of virtual mind maps to describe concepts and problems, audiovisual products of problems and solutions, and virtual posters to communicate project results. The purpose of this research is to explore aspects of planning, designing, analyzing, developing, implementing, and evaluating students' visual thinking continuum process in completing projects of this course.

The qualitative approach in this study is used to analyze aspects of visual thinking, visual learning, and visual communication of student projects. The quantitative approach in this study used one group pretest-posttest design to see the effect of integrating web applications in learning through project-based learning.

\subsection{Participants}

Participants of this study are 54 students of the mathematics department $\left(6^{\text {th }}\right.$ semester) taking courses in the Application of Graph Theory in even semester 20192020. There are two classes, namely TE1 (24 students) and TE2 (30 students).

\subsection{Measurement instrument}

The instruments used in this study are the assessment rubric of the virtual mind maps media, audio-visual media, and virtual poster media. The results of each rubric are analyzed by the Rasch measurement model using WINSTEPS software. The results of summary statistics from the Rasch model provide information about the quality of the instruments and the quality of the student's response patterns to the instruments. Meanwhile, the level of conformity of items with the model is examined from the fit order item. The use of the Rash model can be seen in [54]-[59] and [60]

\section{$4 \quad$ Results / Findings}

Examples of e-projects in the form of virtual mind maps of student designs are shown in Figure 1 and examples of products in the form of virtual posters are shown in Figure 2. 

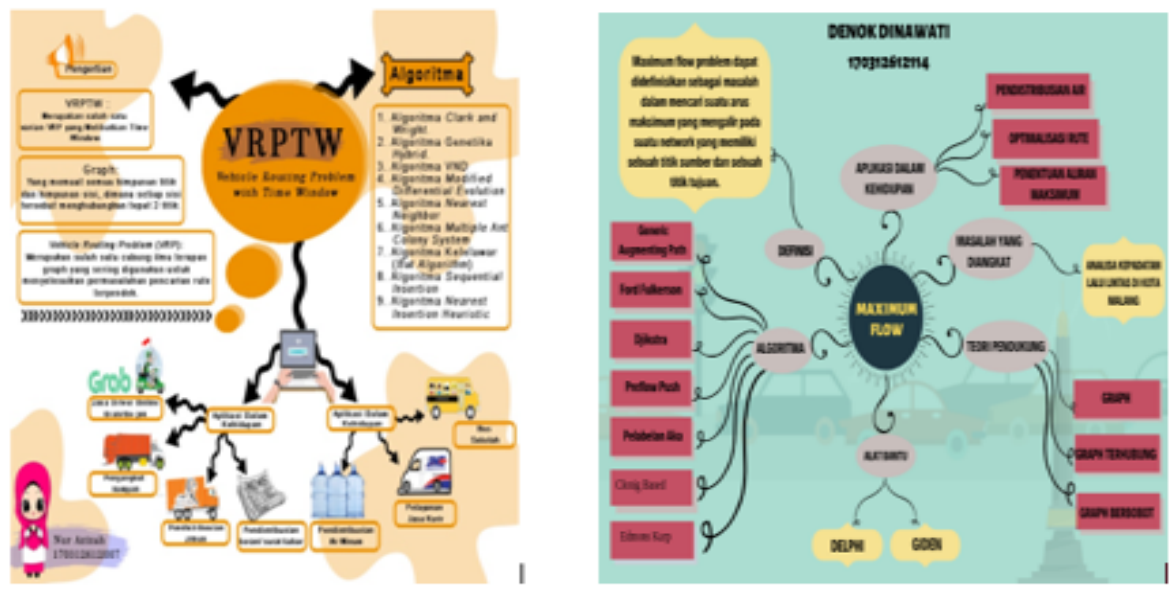

Fig. 1. Examples of student mind map products
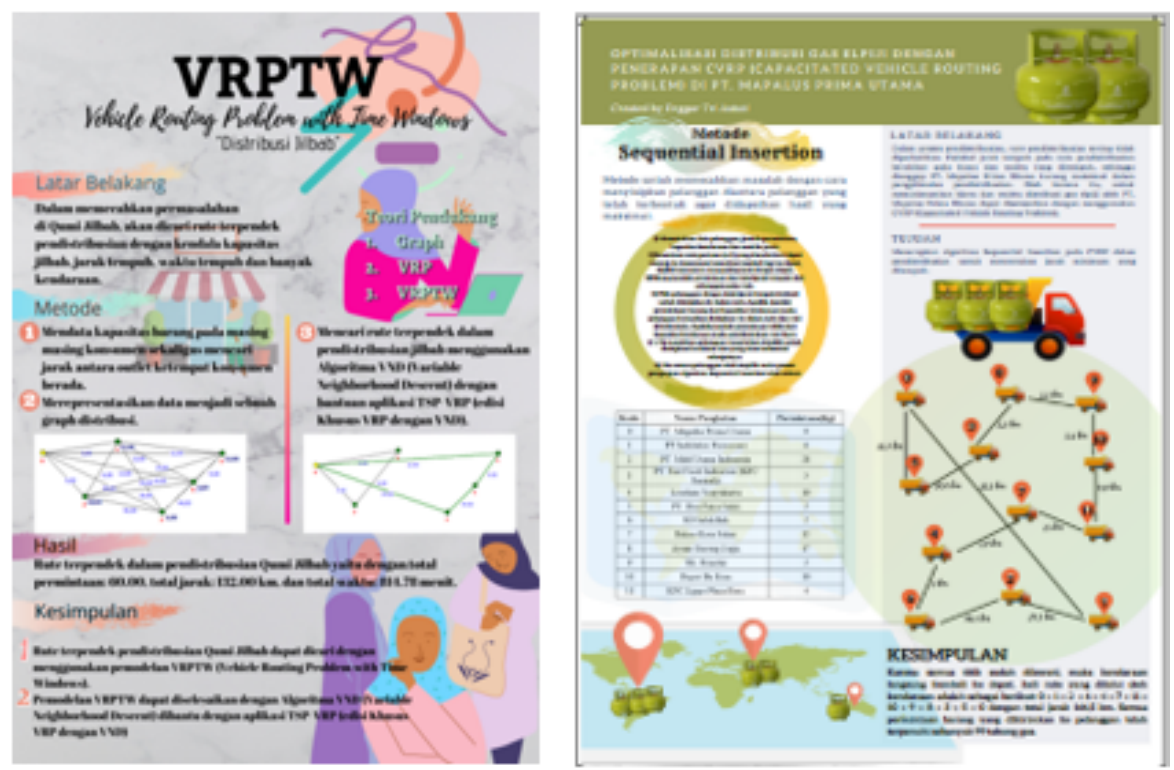

Fig. 2. Examples of student poster products

The following is a summary of statistics in the form of a measured person to see the quality of student response patterns and misfit orders to see the suitability of the measurement model. Table 1. Measured Person Mind maps and Table 2 Misfit Order Mind maps are the Rasch modeling analysis results for the mind maps rubric. Table 3. Measured Person Audio-visual, and Table 4. Misfit Order Audiovisual is the Rasch modeling analysis results for the audiovisual rubric. Table 5. Measured Person Poster and Table 6. Misfit Order Poster is the Rasch modeling analysis results for the poster rubric. 
Table 1. Measured Person Mind maps

\begin{tabular}{|l|c|c|c|c|c|}
\hline \multirow{2}{*}{ MEASURE } & \multirow{2}{*}{ MEA INFIT } & \multicolumn{2}{c|}{ OUTFIT } \\
\cline { 3 - 6 } & & $\boldsymbol{M N S Q}$ & $\boldsymbol{Z S T D}$ & $\boldsymbol{M} \boldsymbol{Q} \boldsymbol{Q}$ & $\boldsymbol{Z S T D}$ \\
\hline MEAN & 1.66 & 0.98 & 0.05 & 0.98 & 0.06 \\
\hline SEM & .42 & 0.02 & 0.05 & 0.02 & 0.05 \\
\hline P.SD & 3.07 & 0.15 & 0.34 & 0.16 & 0.37 \\
\hline S.SD & 3.10 & 0.15 & 0.35 & 0.16 & 0.37 \\
\hline MAX & 5.18 & 1.09 & 0.51 & 1.17 & 0.54 \\
\hline MIN & -3.38 & 0.00 & -1.45 & 0.00 & -1.45 \\
\hline REAL RMSE & Person RELIABILITY 0.89 & & \\
\hline
\end{tabular}

Table 2. Misfit Order Mind maps

\begin{tabular}{|c|c|c|c|c|c|c|c|c|}
\hline \multirow{2}{*}{\begin{tabular}{|c|}
$\begin{array}{c}\text { Entry } \\
\text { Number }\end{array}$ \\
3 \\
\end{tabular}} & \multirow{2}{*}{\begin{tabular}{|c|} 
TOTAL \\
COUNT \\
54 \\
\end{tabular}} & \multirow{2}{*}{$\begin{array}{c}\text { MEASURE } \\
0.11 \\
\end{array}$} & \multicolumn{2}{|c|}{ INFITMNSQ ZSTD } & \multicolumn{2}{|l|}{\begin{tabular}{|l} 
OUTFIT \\
ZSTD
\end{tabular}} & \multirow{2}{*}{\begin{tabular}{|c|}
$\begin{array}{c}\text { PT MEASURE } \\
\text { CORR. }\end{array}$ \\
0.61 \\
\end{tabular}} & \multirow{2}{*}{$\begin{array}{r}\text { Item } \\
\mathrm{K} 3 \\
\end{array}$} \\
\hline & & & 1.05 & 0.53 & 1.05 & 0.35 & & \\
\hline 5 & 54 & 0.19 & 1.03 & 0.34 & 1.05 & 0.38 & 0.72 & K5 \\
\hline 4 & 54 & 0.02 & 1.01 & 0.11 & 1.02 & 0.17 & 0.54 & K4 \\
\hline 2 & 54 & -0.16 & 1.01 & 0.14 & 1.00 & 0.07 & 0.66 & $\mathrm{~K} 2$ \\
\hline 1 & 54 & -0.16 & 0.83 & 1.53 & 0.78 & 1.40 & 0.66 & $\mathrm{~K} 1$ \\
\hline $\begin{array}{l}\text { IEAN } 5 \\
\text { SD } 0.0\end{array}$ & 00.00 & 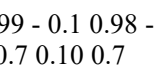 & & & & & & \\
\hline
\end{tabular}

Table 3. Measured Person Audiovisual

\begin{tabular}{|l|c|c|c|c|c|}
\hline \multirow{2}{*}{} & \multirow{2}{*}{ MEASURE } & \multicolumn{2}{|c|}{ INFIT } & \multicolumn{2}{c|}{ OUTFIT } \\
\cline { 3 - 6 } & & $\boldsymbol{M N S Q}$ & $\boldsymbol{Z S T D}$ & $\boldsymbol{M N S Q}$ & $\boldsymbol{Z S T D}$ \\
\hline MEAN & 1.68 & 0.98 & 0.06 & 0.97 & 0.06 \\
\hline SEM & 0.41 & 0.02 & 0.06 & 0.02 & 0.06 \\
\hline P.SD & 2.95 & 0.15 & 0.41 & 0.16 & 0.43 \\
\hline S.SD & 2.98 & 0.15 & 0.41 & 0.16 & 0.43 \\
\hline MAX & 4.42 & 1.09 & 0.79 & 1.12 & 0.80 \\
\hline MIN & -3.72 & 0.00 & -1.43 & 0.00 & -1.43 \\
\hline REAL RMSE & Person RELIABILITY 0.90 & & \\
\hline
\end{tabular}

Table 4. Misfit Order Audiovisual

\begin{tabular}{|c|c|c|c|c|c|c|c|c|}
\hline \multirow{2}{*}{\begin{tabular}{|c}
$\begin{array}{c}\text { Entry } \\
\text { Number }\end{array}$ \\
3 \\
\end{tabular}} & \multirow{2}{*}{$\begin{array}{c}\begin{array}{c}\text { TOTAL } \\
\text { COUNT }\end{array} \\
54 \\
\end{array}$} & \multirow{2}{*}{\begin{tabular}{|c|} 
MEASURE \\
0.00 \\
\end{tabular}} & \multicolumn{2}{|c|}{$\begin{array}{c}\text { INFIT } \\
\text { MNSQ ZSTD } \\
\end{array}$} & \multicolumn{2}{|c|}{$\begin{array}{c}\text { OUTFIT } \\
\text { MNSQ ZSTD } \\
\end{array}$} & \multirow{2}{*}{\begin{tabular}{|c|}
$\begin{array}{c}\text { PT MEASURE } \\
\text { CORR. }\end{array}$ \\
0.54
\end{tabular}} & \multirow{2}{*}{\begin{tabular}{|r|} 
Item \\
$\mathrm{C} 3$ \\
\end{tabular}} \\
\hline & & & 1.10 & 1.13 & 1.06 & 0.45 & & \\
\hline 4 & 54 & 0.25 & 1.10 & 1.07 & 1.06 & 0.47 & 0.55 & $\mathrm{C} 4$ \\
\hline 2 & 54 & 0.00 & 1.05 & 0.56 & 1.06 & 0.50 & 0.69 & $\mathrm{C} 2$ \\
\hline 5 & 54 & -0.08 & 0.93 & 0.72 & 0.95 & 0.32 & 0.64 & $\mathrm{C} 5$ \\
\hline 6 & 54 & -0.25 & 0.91 & -1.01 & 0.87 & 0.94 & 0.68 & C6 \\
\hline 1 & 54 & 0.08 & 0.85 & -1.64 & 0.83 & -1.22 & 0.64 & $\mathrm{C} 1$ \\
\hline \multicolumn{9}{|c|}{$\begin{array}{l}\text { MEAN } \begin{array}{lllllll}54.0 & 0.00 & 0.99 & -0.1 & 0.97 & -0.2 \\
\text { P.SD } & 0.0 & 0.15 & 0.10 & 1.1 & 0.09 & 0.7\end{array}\end{array}$} \\
\hline
\end{tabular}


Table 5. Measured Person Poster

\begin{tabular}{|l|c|c|c|c|c|}
\hline \multirow{2}{*}{ MEASURE } & \multicolumn{2}{|c|}{ INFIT } & \multicolumn{2}{c|}{ OUTFIT } \\
\cline { 3 - 6 } & & $\boldsymbol{M N S Q}$ & $\boldsymbol{Z S T D}$ & $\boldsymbol{M N S Q}$ & $\boldsymbol{Z S T D}$ \\
\hline MEAN & 0.56 & 0.97 & 0.04 & 0.97 & 0.03 \\
\hline SEM & 0.45 & 0.02 & 0.07 & 0.03 & 0.08 \\
\hline P.SD & 3.28 & 0.17 & 0.52 & 0.18 & 0.55 \\
\hline S.SD & 3.31 & 0.18 & 0.53 & 0.19 & 0.56 \\
\hline MAX & 3.91 & 1,19 & 0.94 & 1.22 & 1.02 \\
\hline MIN & -3.91 & 0.00 & -1.35 & 0.00 & -1.35 \\
\hline REAL RMSE & \multicolumn{3}{l}{} \\
\hline
\end{tabular}

Table 6. Misfit Order Poster

\begin{tabular}{|c|c|c|c|c|c|c|c|c|}
\hline \multirow{2}{*}{$\begin{array}{c}\begin{array}{c}\text { Entry } \\
\text { Number }\end{array} \\
2 \\
\end{array}$} & \multirow{2}{*}{$\begin{array}{c}\text { TOTAL } \\
\text { COUNT } \\
54 \\
\end{array}$} & \multirow{2}{*}{$\begin{array}{c}\text { MEASURE } \\
-0.15\end{array}$} & \multicolumn{2}{|c|}{$\begin{array}{c}\text { INFIT } \\
\text { MNSQ ZSTD }\end{array}$} & \multicolumn{2}{|c|}{$\begin{array}{c}\text { OUTFIT } \\
\text { MNSQ ZSTD }\end{array}$} & \multirow{2}{*}{$\begin{array}{c}\text { PT MEASURE } \\
\text { CORR. } \\
0.66 \\
\end{array}$} & \multirow{2}{*}{$\begin{array}{c}\begin{array}{c}\text { Ite } \\
\mathbf{m}\end{array} \\
\mathrm{K} 2\end{array}$} \\
\hline & & & 1.09 & 1.15 & 1.08 & 0.69 & & \\
\hline 4 & 54 & -0.15 & 1.06 & 0.79 & 1.04 & 0.33 & 0.57 & K4 \\
\hline 1 & 54 & 0.02 & 1.04 & 0.46 & 1.01 & 0.15 & 0.77 & K1 \\
\hline 3 & 54 & 0.43 & 0.92 & -0.83 & 0.88 & -0.87 & 0.71 & K3 \\
\hline 5 & 54 & -0.15 & 0.84 & -2.09 & 0.83 & -1.45 & 0.75 & K5 \\
\hline $\begin{array}{lll}\text { MEAN } & 54 . \\
\text { P.SD } & 0.0 & 0\end{array}$ & 00.99 & $\begin{array}{l}0.97-0.2 \\
90.8\end{array}$ & & & & & & \\
\hline
\end{tabular}

To see the effect of integrating web applications in learning through project-based learning analyzed using one group pretest-posttest. The pretest and posttest data normality test was performed with the Kolmogorov-Smirnov before performing the mean difference test for the pretest-posttest. Table 7 the results of the pretest and post-test normality test. The results of the mean difference test for the pretest-posttest are given in Table 8. The results of the analysis of paired samples test from 54 respondents obtained $p$ $<0.05$ so that the base learning project has the effect of increasing students' visual thinking continuum.

Table 7. Pretest and posttest normality Kolmogorov-Smirnov test

\begin{tabular}{|l|c|c|}
\hline & Pretest & Posttest \\
\hline $\mathrm{N}$ & 54 & 54 \\
\hline Mean & 79.1852 & 85.2778 \\
\hline Std. Deviation & 2.21550 & 1.84715 \\
\hline Absolute & .108 & .144 \\
\hline Positive & .097 & .144 \\
\hline Negative & -.108 & -.115 \\
\hline Test Statistic & .108 & .144 \\
\hline Asymp. Sig. (2-tailed & $.167^{\mathrm{c}}$ & $.007^{\mathrm{c}}$ \\
\hline & & Test distribution is Normal \\
\hline
\end{tabular}




\section{Discussions}

Table 8. The mean difference test

\begin{tabular}{|c|c|c|c|c|c|c|c|c|}
\hline & \multicolumn{5}{|c|}{ Paired Differences } & \multirow{3}{*}{ t } & \multirow{3}{*}{ df } & \multirow{3}{*}{$\begin{array}{l}\text { Sig }(2- \\
\text { tailed) }\end{array}$} \\
\hline & \multirow[b]{2}{*}{ Mean } & \multirow[b]{2}{*}{ S. D } & \multirow[t]{2}{*}{\begin{tabular}{|c} 
Std Error \\
mean
\end{tabular}} & \multicolumn{2}{|c|}{$\begin{array}{l}\text { 95\% Confidence } \\
\text { interval of the diff }\end{array}$} & & & \\
\hline & & & & Lower & Upper & & & \\
\hline $\begin{array}{l}\text { Pre-Post } \\
\text { Test }\end{array}$ & -6.093 & 1.533 & 0.209 & -6.511 & -6.511 & -29.207 & 53 & 0.000 \\
\hline
\end{tabular}

The Rasch measure model can be used to analyze instruments such as referring to previous research for validation [61] and [62], ability [57], and reliability level for each student's responses [58]. The results of measured persons for virtual mind mapss, audiovisuals, and virtual posters are shown in Table 1, Table 3, and Table 5. These results indicate the quality of student response patterns to the instrument. Person reliability criteria are shown in Table 9 refer to [63].

The results of the measured person for the virtual mind maps, audiovisual, and virtual poster are shown in Table 1, Table 3 , and Table 5 . These results indicate the quality of student response patterns to the instrument. Person reliability criteria are shown in Table 9 below.

Table 9. Criteria Person Reliability

\begin{tabular}{|l|c|}
\hline \multicolumn{1}{|c|}{ Criteria } & Person Reliability \\
\hline Poor & $<0.67$ \\
\hline Fair & $0.67-0.80$ \\
\hline Good & $0.81-0.90$ \\
\hline Very Good & $0.91-0.94$ \\
\hline Excellent & $>0.94$ \\
\hline
\end{tabular}

From the person measure table, the person reliability value for the virtual mind maps is 0.89 (Good), the person reliability value for audiovisual is 0.90 (Good), the person reliability value for the virtual poster is 0.91 (Very Good). Other data that can be used to see the quality of student responses are the mean INFIT MNSQ, OUTFIT MNSQ with ideal criteria of 1.00, and mean INFIT ZSTD, OUTFIT ZSTD with ideal criteria of 0.0 . In Table 1, for the virtual mind maps, the mean INFIT MNSQ and OUTFIT MNSQ is 0.98 , the mean INFIT ZSTD is 0.05 and the mean OUTFIT ZSTD is 0.06 . In Table 3, for the audiovisual, the mean INFIT MNSQ is 0.98 and mean OUTFIT MNSQ is 0.97 , the mean INFIT ZSTD and OUTFIT ZSTD is 0.06 . In Table 5 , for the virtual poster, the mean INFIT MNSQ and OUTFIT MNSQ are 0.97, the mean INFIT ZSTD is 0.04 and the mean OUTFIT ZSTD is 0.03 . The results of the Rash model analysis for the person measure show that the overall student response pattern is good.

The results of the misfit orders for virtual mind maps, audiovisual, and virtual posters are shown in Table 2, Table 4, and Table 6 . These results indicate the suitability level of the instrument with the ideal measurement model. The criteria for fit items are shown in Table 10 refer to [63]. 
Table 10. Criteria of the misfit orders

\begin{tabular}{|l|l|}
\hline \multicolumn{1}{|c|}{ Indikator } & \multicolumn{1}{c|}{ Ideal criteria } \\
\hline Infit Means Square (Infit MNSQ) & $0.5<$ Infit MNSQ $<1.5$ \\
\hline Outfit Mean Square (outfit MNSQ) & $0.5<$ outfit MNSQ $<1.5$ \\
\hline Infit Z-standard (infit ZSTD) & $-2.0<$ infit ZSTD $<+2.0$ \\
\hline Outfit Z-standard (outfit ZSTD) & $-2.0<$ outfit ZSTD $<+2.0$ \\
\hline Point measure correlation (Pt Measure Corr) & $0.4<$ Pt Measure Corr $<0.85$ \\
\hline
\end{tabular}

In Table 2, the mind maps misfit order can be seen that all items K1, K2, K3, K4, K5 fulfill $0.5<$ Infit MNSQ $<1.5,0.5<$ outfit MNSQ $<1.5,-2.0<$ infit ZSTD $<+2.0$, $2.0<$ outfit ZSTD $<+2.0$ and $0.4<\mathrm{Pt}$ Measure Corr $<0.85$. It can be said that the level of conformity of the instrument with the measurement model is accepted.

In Table 4 the audiovisual order misfit can be seen that all items $\mathrm{C} 1, \mathrm{C} 2, \mathrm{C} 3, \mathrm{C} 4$, C5, C6 fulfill $0.5<$ Infit MNSQ $<1.5,0.5<$ outfit MNSQ $<1.5,-2.0<$ infit ZSTD $<+2.0,-2.0<$ outfit ZSTD $<+2.0$ and $0.4<$ Pt Measure Corr $<0.85$. It can be said that the level of conformity of the instrument with the measurement model is accepted.

In Table 6, the poster's misfit order can be seen that items K1, K2, K3, K4, K5 fulfill $0.5<$ Infit MNSQ $<1.5,0.5<$ outfit MNSQ $<1.5,-2.0<$ outfit ZSTD $<+2.0$ and 0.4 $<$ Pt Measure Corr $<0.85$. At K5 infit ZSTD $=-2.09$. In general, it can still be said that the suitability level of the instrument with the measurement model is accepted.

The results of the analysis of the Rasch measurement model, rubric virtual mind maps, audio-visual, and virtual poster developed can be used to measure students' visual thinking, visual learning, and visual communication.

To observe the effect of the application of project-based learning in learning, two tests were carried out, namely the pretest and posttest. A paired t-test was performed using SPSS. Each pretest and posttest data was carried out a normal test using the Kolmogorov-Smirnov test, the results of which were both normally distributed can be seen in Table 7. The results of the paired t-test can be seen in Table 8 with a 95\% confidence level obtained $\mathrm{p}<0.05$ so that there is an effect of the application of project-based learning on students' visual thinking continuum.

\section{Conclusion}

In this investigation, we assessed project-based learning by identifying theory and problem solving with virtual mind mapss. Learning products in the form of audiovisuals and communicating the results in the form of virtual posters could be applied to observe students' visual thinking continuum. Virtual mind mapss are used to observe visual thinking, audiovisual to observe visual learning, and virtual posters to observe student visual communication.

\section{$7 \quad$ Suggestions for Future Research}

As a result of conducting this research, I propose that the study of visual thinking continuum needs to be developed again in the field of mathematics studies or other 
fields of study. The use of the Rasch measurement model in this article examines two things: Measured Person and Misfit Order. Further studies include the analysis of the Person-Item Map, Person Measure, Person Fit Order, Guttman Scalogram, and Item DIF.

\section{Acknowledgement}

This article is a part of research funded by PNBP UM, contract no: 4.3.476/UN32.14.1/LT/2020, entitled "Promoting Students' Visual Thinking Continuum Through Project-Based Learning with Integration of Web Applications". Thank you to Universitas Negeri Malang for Funding the Research.

\section{$9 \quad$ References}

[1] Favale T., Soro F., Trevisan M., Drago I., and Mellia M., "Campus traffic and e-Learning during COVID-19 pandemic," Comput. Netw., vol. 176, p. 107290, Jul. 2020, https://doi.org/10.1016/j.comnet. 2020.107290

[2] DeFilippis E. M., Stefanescu Schmidt A. C., and Reza N., "Adapting the Educational Environment for Cardiovascular Fellows-in-Training During the COVID-19 Pandemic," J. Am. Coll. Cardiol., vol. 75, no. 20, pp. 2630-2634, May 2020, https://doi.org/10.1016/j.jacc.2020.04.013

[3] Jowsey T., Foster G., Cooper-Ioelu P., and Jacobs S., "Blended learning via distance in pre-registration nursing education: A scoping review," Nurse Educ. Pract., vol. 44, p. 102775, Mar. 2020, https://doi.org/10.1016/j.nepr.2020.102775

[4] Almarzooq Z. I., M. Lopes, and A. Kochar, "Virtual Learning During the COVID-19 Pandemic," J. Am. Coll. Cardiol., vol. 75, no. 20, pp. 2635-2638, May 2020, https://doi.org/10.1016/j.jacc.2020.04.015

[5] Riley E., L. Haggard-Duff, and C. R. Long, "Using an online learning module to teach nursing students about food insecurity as a social determinant of health," Teach. Learn. Nurs., p. S1557308720300470, May 2020, https://doi.org/10. 1016/j.teln.2020.04.007

[6] Persada S. F., A. Oktavianto, B. Miraja, R. Nadlifatin, P. F. Belgiawan, and A.A. N. P. Perwira Redi, "Public Perceptions of Online Learning in Developing Countries: A Study Using The ELK Stack for Sentiment Analysis on Twitter," Int. J. Emerg. Technol. Learn. IJET, vol. 15, no. 09, p. 94, May 2020, https://doi.org/10.3991/ijet.v15i09.11579

[7] Beach P., "Examining Elementary Teachers' Use of Online Learning Environments: An Exploratory Study," J. Res. Technol. Educ., vol. 50, no. 1, pp. 34-47, Jan. 2018, DOI: $10.1080 / 15391523.2017$. 1383216.

[8] Brown J. A. L, "Producing scientific posters, using online scientific resources, improves applied scientific skills in undergraduates," J. Biol. Educ., vol. 54, no. 1, pp. 77-87, Jan. 2020, https://doi.org/10. 1080/00219266.2018.1546758

[9] Kumi-Yeboah A., J. Dogbey, and G. Yuan, "Exploring Factors That Promote Online Learning Experiences and Academic Self-Concept of Minority High School Students," J. Res. Technol. Educ., vol. 50, no. 1, pp. 1-17, Jan. 2018, https://doi.org/10.1080/15391523.2017.1365669

[10] Astriani D., H. Susilo, H. Suwono, B. Lukiati, and A. R. Purnomo, 'Mind Mapping in Learning Models: A Tool to Improve Student Metacognitive Skills', Int. J. 
Emerg.Technol. Learn., vol. 15, no. 06, p. 4, Mar. 2020, https://doi.org/10.3991/ijet.v15i06.12657

[11] Simonova I., "E-learning in Mind Maps of Czech and Kazakhstan University Students," Procedia - Soc. Behav. Sci., vol. 171, pp. 1229-1234, Jan. 2015, https://doi.org/10.1016/j.sbspro.2015.01.236

[12] Bystrova T. and Larionova V., "Use of Virtual Mind Mapping to Effectively Organise the Project Activities of Students at the University," Procedia - Soc. Behav. Sci., vol. 214, pp. 465-472, Dec. 2015, https://doi.org/10.1016/j.sbspro. 2015.11.724

[13] Abrams Z. I. and D. R. Byrd, "The effects of pre-task planning on L2 writing: Mindmapping and chronological sequencing in a 1st-year German class," System, vol. 63, pp. 1-12, Dec. 2016, https://doi.org/10.1016/j.system. 2016.08.011

[14] Dirnberger D., "The use of mind mapping software for patent search and management," World Pat. Inf., vol. 47, pp. 12-20, Dec. 2016, https://doi.org/10.1016/j.wpi.2016.08.004

[15] Fellnhofer K., "Toward a taxonomy of entrepreneurship education research literature: A bibliometric mapping and visualization," Educ. Res. Rev., vol. 27, pp. 28-55, Jun. 2019, https://doi.org/10. 1016/i.edurev. 2018.10.002

[16] Frerichs L., T. L. Young, G. Dave, D. Stith, G. Corbie-Smith, and K. Hassmiller Lich, "Mind maps and network analysis to evaluate conceptualization of complex issues: A case example evaluating systems science workshops for childhood obesity prevention," Eval. Program Plann., vol. 68, pp. 135-147, Jun. 2018, https://doi.org/10.1016/j.evalprogplan.2018.03.003

[17] Fu Q.-K., C.-J. Lin, G.-J. Hwang, and L. Zhang, "Impacts of a mind mapping-based contextual gaming approach on EFL students' writing performance, learn-ing perceptions and generative uses in an English course," Comput. Educ., vol. 137, pp. 59-77, Aug. 2019, https://doi.org/10.1016/j.compedu.2019.04.005

[18] $\mathrm{Hu}$ M., T. Shealy, J. Grohs, and R. Panneton, "Empirical evidence that concept mapping reduces neurocognitive effort during concept generation for sustainability," J. Clean. Prod., vol. 238, p. 117815, Nov. 2019, https://doi.org/10.1016/j.jclepro.2019.117815

[19] Liu Y., Y. Tong, and Y. Yang, "The Application of Mind Mapping into College Computer Programming Teaching," Procedia Comput. Sci., vol. 129, pp. 66-70, 2018, https://doi.org/10.1016/j.procs.2018.03.047

[20] Thuneberg H. M., H. S. Salmi, and F. X. Bogner, "How creativity, autonomy, and visual reasoning contribute to cognitive learning in a STEAM hands-on inquiry-based math module," Think. Ski. Creat., vol. 29, pp. 153-160, Sep. 2018, https://doi.org/10.1016/j.tsc.2018.07.003

[21] S., N. Seppala, and N. Sadowska, "Facilitating creative thinking in the classroom: Investigating the effects of plants and the color green on visual and verbal creativity," Think. Ski. Creat., vol. 19, pp. 1-8, Mar. 2016, https://doi.org/10.1016/j.tsc.2015.09.001

[22] Doron E., "Fostering creativity in school-aged children through perspective-taking and visual media based short term intervention program," Think. Ski. Creat., vol. 23, pp. 150160, Mar. 2017, https://doi.org/10.1016/j.tsc.2016.12.003

[23] Atan N. A., "Profil Kontinum Pemikiran Visual Pelajar Menerusi Persekitaran Pembelajaran Autentik Bervisual," Universiti Teknologi Malaysia, Malaysia,2012.

[24] Frankel A. M. and D. A. Trauner, "Visual and verbal learning and memory in cystinosis," Brain Cogn., vol. 135, p. 103578, Oct. 2019, https://doi.org/10.1016/j.bandc.2019.103578

[25] Pezzino M., "Online assessment, adaptive feedback, and the importance of visual learning for students. The advantages, with a few caveats, of using MapleTA," Int. Rev. Econ. Educ., vol. 28, pp. 11-28, May 2018, https://doi.org/10.1016/j.iree.2018.03.002

[26] Vieira C., P. Parsons, and V. Byrd, "Visual learning analytics of educational data:A systematic literature review and research agenda," Comput. Educ., vol. 122, pp.119-135, Jul. 
2018

$\underline{\text { https://doi.org/10.1016/ }}$

j.compedu.2018.03.018

[27] Wang J., P. Antonenko, and K. Dawson, "Does visual attention to the instructor in online video affect learning and learner perceptions? An eye-tracking analysis," Comput. Educ., vol. 146, p. 103779, Mar. 2020, https://doi.org/10.1016/j.compedu.2019.103779

[28] Adiloglu F., "Visual communication: design studio education through working the process," Procedia - Soc. Behav. Sci., vol. 28, pp. 982-991, 2011, https://doi.org/10.1016/j.sbspro.2011.11.182

[29] Pressgrove G., M. Janoski, and M. J. Haught, "Editors' letter: New research and opportunities in public relations and visual communication," Public Relat. Rev., vol. 44, no. 3, pp. 317-320, Sep. 2018, https://doi.org/10.1016/j.pubrev.2018.04.006

[30] Raoufi K., C. Taylor, L. Laurin, and K. R. Haapala, "Visual Communication Methods and Tools for Sustainability Performance Assessment: Linking Academic and Industry Perspectives," Procedia CIRP, vol. 80, pp. 215-220, 2019, https://doi.org/10.1016/j.procir. 2019.01.087

[31] Ståhl M.and H. Kaihovirta, "Exploring visual communication and competencies through interaction with images in social media," Learn. Cult. Soc. Interact., vol. 21, pp. 250-266, Jun. 1016/j.lcsi.2019.03.003 2019 ,

https://doi.org/10.

[32] Altintas N. N., A. Z. Suer, E. S. Sari, and M. S. Ulker, "The Use of Poster Projects as a Motivational and Learning Tool in Managerial Accounting Courses," J. Educ. Bus., vol. 89, no. 4, pp. 196-201, May 2014, https://doi.org/10.1080/08832323.2013.840553

[33] Yan L.and X. Wang, "Why posters contribute different content in their positive online reviews: A social information-processing perspective," Comput. Hum. Behav., vol. 82, pp. 199-216, May 2018, https://doi.org/10.1016/j.chb.2018.01.009

[34] Young J., M. B. Bridgeman, and E. R. Hermes-DeSantis, "Presentation of scientific poster information: Lessons learned from evaluating the impact of content arrangement and use of infographics," Curr. Pharm. Teach. Learn., vol. 11, no. 2, pp. 204-210, Feb. 2019, https://doi.org/10.1016/j.cptl.2018.11.011

[35] Arcidiacono G., K. Yang, J. Trewn, and L. Bucciarelli, "Application of Axiomatic Design for Project-based Learning Methodology," Procedia CIRP, vol. 53, pp. 166-172, 2016, https://doi.org/10.1016/j.procir.2016.08.003

[36] Efstratia D., "Experiential Education through Project-Based Learning," Procedia - Soc. Behav. Sci., vol. 152, pp. 1256-1260, Oct. 2014, https://doi.org/10.1016/j.sbspro.2014.09.362

[37] Gülbahar Y. and H. Tinmaz, "Implementing Project-Based Learning And E-Port-folio Assessment in an Undergraduate Course," J. Res. Technol. Educ., vol. 38, no. 3, pp. 309 327, Mar. 2006, https://doi.org/10.1080/15391523.2006. 10782462

[38] Kettanun C., "Project-based Learning and Its Validity in a Thai EFL Classroom," Procedia - Soc. Behav. Sci., vol. 192, pp. 567-573, Jun. 2015, https://doi.org/10.1016/j.sbspro.2015.06.094

[39] Santos L. B., P. H. F. Xavier, J. V. C. Santos, and R. R. Sampaio, 'Teaching of Ordinary Differential Equations Using the Assumptions of the PBL Method', Int. J. Eng. Ped., vol. 10, no. 3, p. 7, May 2020, https://doi.org/10.3991/ijep.v10i3.12015

[40] Luo Y. and W. Wu, "Sustainable Design with BIM Facilitation in Project-based Learning," Procedia Eng., vol. 118, pp. 819-826, 2015, https://doi.org/10.1016/j.proeng.2015.08.519

[41] Tasc1 B. G., "Project-Based Learning from Elementary School to College, Tool: Architecture," Procedia - Soc. Behav. Sci., vol. 186, pp. 770-775, May 2015, https://doi.org/10.1016/j.sbspro.2015.04. $\underline{130}$ 
[42] Voronchenko T., T. Klimenko, and I. Kostina, "Learning to Live in a GlobalWorld: Project-Based Learning in Multicultural Student Groups as a Pedagogy of Tolerance Strategy," Procedia - Soc. Behav. Sci., vol. 191, pp. 1489-1495, Jun. 2015, https://doi.org/10.1016/j.sbspro.2015.04.472

[43] Ciftci S. "The Effects of Using Project-Based Learning in Social Studies Edu-cation to Students' Attitudes towards Social Studies Courses,” Procedia - Soc. Behav. Sci., vol. 186, pp. 1019-1024, May 2015, https://doi.org/10.1016/j.sbspro.2015.04.205

[44] Kogtikov N., A. Dukhanov, and K. Bochenina, "Modeling Knowledge Transfer and the Transdisciplinary Effect on Project-based Learning Activities," Procedia Comput. Sci., vol. 80, pp. 1989-1999, 2016, https://doi.org/10.1016/j.procs.2016.05.519

[45] Sart G., "The Effects of the Development of Metacognition on Project-basedLearning," Procedia - Soc. Behav. Sci., vol. 152, pp. 131-136, Oct. 2014, DOI: 10.1016/j.sbspro.2014.09.169.

[46] Balan L., T. Yuen, and M. Mehrtash, "Problem-Based Learning Strategy for CAD Software Using Free-Choice and Open-Ended Group Projects," Procedia Manuf., vol. 32, pp. 339-347, 2019, https://doi.org/10.1016/i.promfg.2019.02.223

[47] García C., "Project-based Learning in Virtual Groups - Collaboration and Learn-ing Outcomes in a Virtual Training Course for Teachers," Procedia - Soc. Behav. Sci., vol. 228, pp. 100-105, Jul. 2016, https://doi.org/10.1016/j.sbspro.2016.07.015

[48] Splichal J. M., J. Oshima, and R. Oshima, "Regulation of collaboration in project-based learning mediated by CSCL scripting reflection," Comput. Educ., vol. 125, pp. 132-145, Oct. 2018, https://doi.org/10.1016/j.compedu.2018.06.003

[49] Yamashita K. and H. Yasueda, "Project-based learning in out-of-class activities: flipped learning based on communities created in real and virtual spaces," Procedia Comput. Sci., vol. 112, pp. 1044-1053, 2017, https://doi.org/10.1016/j.procs.2017.08.108

[50] Nadiyah R. S. and S. Faaizah, "The Development of Online Project-Based Collaborative Learning Using ADDIE Model," Procedia - Soc. Behav. Sci., vol. 195, pp. 1803-1812, Jul. 2015 , 1016/j.sbspro.2015.06.392

https://doi.org/10.

[51] Vila C., D. Ugarte, J. Ríos, and J. V. Abellán, "Project-based collaborative engineering learning to develop Industry 4.0 skills within a PLM framework," Pro-cedia Manuf., vol. 13, pp. 1269-1276, 2017, https://doi.org/10.1016/j.promfg.2017.09.050

[52] Li J., Antonenko P. D., and Wang J., "Trends and issues in multimedia learning research in 1996-2016: A bibliometric analysis," Educ. Res. Rev., vol. 28, p. 100282, Nov. 2019, https://doi.org/10.1016/ j.edurev.2019.100282

[53] Stettler M.and G. Francis, "Using a model of human visual perception to improve deep learning," Neural Netw., vol. 104, pp. 40-49, Aug. 2018, https://doi.org/10.1016/j.neunet.2018.04.005

[54] Abbakumov D., P. Desmet, and W. Van den Noortgate, "Measuring student's proficiency in MOOCs: multiple attempts extensions for the Rasch model," Heli-yon, vol. 4, no. 12, p. e01003, Dec. 2018, https://doi.org/10.1016/j.heliyon.2018.e01003

[55] Asshaari I., H. Othman, H. Bahaludin, N. A. Ismail, and Z. M. Nopiah, "Appraisal on Bloom's Separation in Final Examination Question of Engineering Mathematics Courses using Rasch Measurement Model," Procedia - Soc. Behav. Sci., vol. 60, pp. 172-178, Oct. 2012, https://doi.org/10.1016/j.sbspro.2012.09.364

[56] Briggs D. C., "Interpreting and visualizing the unit of measurement in the Rasch Model," Measurement, vol. 146, pp. 961-971, Nov. 2019, https://doi.org/10.1016/j.measurement.2019.07.035

[57] Chan S. W., Z. Ismail, and B. Sumintono, "A Rasch Model Analysis on Secondary Students' Statistical Reasoning Ability in Descriptive Statistics," Procedia - Soc. Behav. Sci., vol. 129, pp. 133-139, May 2014, https://doi.org/10.1016/j.sbspro.2014.03.658 
[58] Mamat M. N., P. Maidin, and F. Mokhtar, "Simplified Reliable Procedure for Producing Accurate Student's Ability Grade Using Rasch Model," Procedia - Soc. Behav. Sci., vol. 112, pp. 1077-1082, Feb. 2014, https://doi.org/10.1016/j.sbspro.2014.01.1272

[59] Wati M., S. Mahtari, S. Hartini, and H. Amelia, "A Rasch Model Analysis on Junior High School Students' Scientific Reasoning Ability,” Int. J. Interact. Mob. Technol. IJIM, vol. 13, no. 07, p. 141, Jul. 2019, https://doi.org/10.3991/ijim.v13i07.10760

[60] Widhiarso W. and Sumintono B., "Examining response aberrance as a cause of outliers in statistical analysis," Personal. Individ. Differ., vol. 98, pp. 11-15, Aug. 2016, https://doi.org/10.1016/j.paid. 2016.03.099

[61] Alnahdi G. H., "Rasch validation of the Arabic version of the Teacher Efficacy for Inclusive Practices (TEIP) scale," Stud. Educ. Eval., vol. 62, pp. 104-110, Sep. 2019, https://doi.org/10.1016/j.stueduc. 2019.05.004

[62] Jacob E. R., C. Duffield, and A. M. Jacob, "Validation of data using RASCH analysis in a tool measuring changes in critical thinking in nursing students," Nurse Educ. Today, vol. 76, pp. 196-199, May 2019, https://doi.org/10.1016/j.nedt.2019.02.012

[63] Sumintono B., "Aplikasi Pemodelan Rasch pada Asesmen Pendidikan”. Cetakan I, September 2015, Trim Komunikasi

\section{Authors}

Sapti Wahyuningsih is an associate professor at Faculty Science, and Mathematics, Universitas Negeri Malang. Her research interests include applied mathematics and disruptive learning innovations in higher education. Email: sapti.wahyuningsih.fmipa@um.ac.id

Darmawan Satyananda is a senior lecturer at Faculty Science, and Mathematics, Universitas Negeri Malang. His research interests include graph application and computing methods in the distribution process.

Abd Qohar is an associate professor at Faculty Science and Mathematics,

Universitas Negeri Malang. His research interests include Mathematics education, IT-based learning, and curriculum development.

Noor Azean Binti Atan is a senior lecturer, Department of Science, Mathematics Education and Creative Multimedia Faculty of Education, Universiti Teknologi Malaysia. Her research interests include Creative and Innovative Technologies in Education

Article submitted 2021-01-28. Resubmitted 2021-03-05. Final acceptance 2021-03-07. Final version published as submitted by the authors. 